\title{
GMFCS and spino-pelvi-femoral complex in ambulating or walking cerebral palsy children. retrospective study
}

Jean-Claude Bernard ${ }^{1 *}$, Julie Deceuninck ${ }^{1}$, Emmanuelle Chaleat-Valayer ${ }^{1}$, Jessica Sutton ${ }^{1}$, Sophie Leroy-Coudeville', Edith Morel ${ }^{1}$, Eric Loustalet ${ }^{1}$, Audrey Combey ${ }^{1}$, Eric Berthonnaud ${ }^{2}$

From 11th International Conference on Conservative Management of Spinal Deformities - SOSORT 2014

Annual Meeting

Wiesbaden, Germany. 8-10 May 2014

\section{Introduction}

We have performed a radiological evaluation of static data of spine-pelvis-femur complex in walking children with cerebral palsy (CP). The data are discussed about GMFCS and after about radiological data in asymptomatic subjects.

\section{Materials and methods}

The CP population is comprised of 119 children and the asymptomatic population of 652 children.

\section{Results}

There is no significative difference concerning the form parameter (pelvic incidence $=\mathrm{PI}$ ), on the other hand there is a significative difference on position parameters (pelvic tilt $=\mathrm{PT}$ and sacral slope $=\mathrm{SS}$ ). There is a correlation between GMFCS and PI $(\mathrm{p}=0.013)$ and between GMFCS and PT $(\mathrm{p}=0.021)$.

\section{Discussion}

The PC population is not structurally different than the asymptomatic population. It will be the growth, in pathologic context, which disturb parameters. A lumbar lordosis which is not correlated with PI have to be consider like a result of the disease (postural troubles, neuro-motor disorders related with growth,...) and require a specific and early evaluation and treatment.
Authors' details

${ }^{1}$ CMCR des Massues, Lyon, France. ${ }^{2}$ Hopital Nord Ouest, Villefranche sur

Saone, France.

Published: 4 December 2014

doi:10.1186/1748-7161-9-S1-052

Cite this article as: Bernard et al:: GMFCS and spino-pelvi-femoral

complex in ambulating or walking cerebral palsy children. retrospective

study. Scoliosis 2014 9(Suppl 1):O52.

${ }^{1}$ CMCR des Massues, Lyon, France

Full list of author information is available at the end of the article

Submit your next manuscript to BioMed Central and take full advantage of:

- Convenient online submission

- Thorough peer review

- No space constraints or color figure charges

- Immediate publication on acceptance

- Inclusion in PubMed, CAS, Scopus and Google Scholar

- Research which is freely available for redistribution
() Biomed Central 